\title{
Three-dimensional imaging in myotonic dystrophy type 1
}

\author{
Linking molecular alterations with disease phenotype
}

\begin{abstract}
Alfonsina Ballester-Lopez, MSc, Judit Núñez-Manchón, MSc, Emma Koehorst, MSc, lan Linares-Pardo, Miriam Almendrote, MD, Giuseppe Lucente, MD, Nicolau Guanyabens, MD, Marta Lopez-Osias, BSc, Adrián Suárez-Mesa, MSc, Shaliza Ann Hanick, MSc, Jakub Chojnacki, PhD, Alejandro Lucia, MD, PhD, Guillem Pintos-Morell, MD, PhD, Jaume Coll-Cantí, MD, PhD, Alicia Martínez-Piñeiro, MD,*

Alba Ramos-Fransi, MD, PhD, * and Gisela Nogales-Gadea, PhD*
\end{abstract}

Neurol Genet 2020;6:e484. doi:10.1212/NXG.0000000000000484

\section{Abstract \\ Objective}

We aimed to determine whether 3D imaging reconstruction allows identifying molecular: clinical associations in myotonic dystrophy type 1 (DM1).

\section{Methods}

We obtained myoblasts from 6 patients with DM1 and 6 controls. We measured cytosinethymine-guanine (CTG) expansion and detected RNA foci and muscleblind like 1 (MBNL1) through 3D reconstruction. We studied dystrophia myotonica protein kinase (DMPK) expression and splicing alterations of MBNL1, insulin receptor, and sarcoplasmic reticulum $\mathrm{Ca}(2+)$-ATPase 1 .

\section{Results}

Three-dimensional analysis showed that RNA foci (nuclear and/or cytoplasmic) were present in $45 \%-100 \%$ of DM1-derived myoblasts we studied (range: 0-6 foci per cell). RNA foci represented $<0.6 \%$ of the total myoblast nuclear volume. CTG expansion size was associated with the number of RNA foci per myoblast $(r=0.876$ [95\% confidence interval 0.222-0.986]) as well as with the number of cytoplasmic RNA foci $(r=0.943$ [0.559-0.994]). Although MBNL1 colocalized with RNA foci in all DM1 myoblast cell lines, colocalization only accounted for $1 \%$ of total MBNL1 expression, with the absence of DM1 alternative splicing patterns. The number of RNA foci was associated with DMPK expression $(r=0.967$ [0.079-0.999]). On the other hand, the number of cytoplasmic RNA foci was correlated with the age at disease onset $(r=-0.818[-0.979$ to 0.019$])$.

\section{Conclusions}

CTG expansion size modulates RNA foci number in myoblasts derived from patients with DM1. MBNL1 sequestration plays only a minor role in the pathobiology of the disease in these cells. Higher number of cytoplasmic RNA foci is related to an early onset of the disease, a finding that should be corroborated in future studies.

\author{
Correspondence \\ Dr. Nogales-Gadea \\ gnogales@igtp.cat
}

\section{MORE ONLINE}

- Video

\footnotetext{
*These authors contributed equally to this work.

From the Neuromuscular and Neuropediatric Research Group (A.B.-L., J.N.-M., E.K., I.L.-P., M.A., G.L., M.L.-O., A.S.-M., S.A.H., G.P.-M., J.C.-C., A.M.-P., A.R.-F., G.N.-G.), Institut d'Investigació en Ciències de la Salut Germans Trias i Pujol, Campus Can Ruti, Universitat Autònoma de Barcelona, Badalona; Centro de Investigación Biomédica en Red de Enfermedades Raras (CIBERER) (A.B.-L., G.P.-M., J.C.-C., G.N.-G.), Instituto de Salud Carlos III, Madrid; Neuromuscular Pathology Unit. Neurology Service. Neuroscience department (M.A., G.L., N.G., J.C.-C., A.M.-P., A.R.-F.), Hospital Universitari Germans Trias i Pujol, Badalona, Barcelona; IrsiCaixa AIDS Research Institute (J.C.), Badalona, Spain; Faculty of Sport Sciences (A.L.), Universidad Europea de Madrid; Instituto de Investigación Hospital 12 de Octubre (i+12) (A.L.), Madrid; and Division of Rare Diseases. University Hospital Vall d'Hebron (G.P.-M.), Barcelona, Spain.
}

Go to Neurology.org/NG for full disclosures. Funding information is provided at the end of the article.

The Article Processing Charge was funded by the authors.

This is an open access article distributed under the terms of the Creative Commons Attribution-NonCommercial-NoDerivatives License 4.0 (CC BY-NC-ND), which permits downloading and sharing the work provided it is properly cited. The work cannot be changed in any way or used commercially without permission from the journal. 


\section{Glossary}

CI = confidence interval; DM1 = myotonic dystrophy type 1; DMPK = dystrophia myotonica protein kinase; IR = insulin receptor; MBNL1 = muscleblind like 1; $\mathbf{m R S}=$ modified Rankin Scale; $\mathbf{q P C R}=$ quantitative PCR; RT-PCR = reverse transcription PCR.

Myotonic dystrophy type I (DM1) is a multisystemic disorder with autosomal dominant inheritance caused by a cytosinethymine-guanine (CTG) repeat expansion in the $3^{\prime}$ UTR of the dystrophia myotonica protein $(D M P K)$ gene. ${ }^{1}$ The main pathogenic process underlying DM1 is a toxic RNA gain-offunction effect of expanded DMPK transcripts forming hairpinstructured aggregates, called "RNA foci.",3 These aggregates are able to sequester splicing factors, thereby affecting the alternative splicing of some pre-mRNAs such as insulin receptor (IR), sarcoplasmic/endoplasmic reticulum $\mathrm{Ca}(2+)$-ATPase 1 (ATP2A1), ${ }^{4,5}$ or muscleblind like 1 (MBNL1). ${ }^{6}$

Most studies on DM1 have relied on 2D imaging at a single cell level. Yet, this classic approach does not allow detection of all RNA foci aggregates nor identification of their location inside cells. In addition, with this technique, it is not possible to identify the distribution and sequestration of MBNL1 protein. These limitations have hindered recognition of the full cascade of molecular events associated with the phenotype manifestation of DM1.

Here, we used 3D imaging in whole myoblasts derived from patients with DM1 with different degrees of affectation in an attempt to gain insight into the link between DM1 molecular players and disease phenotype. Thus, we assessed the relationship between CTG repeat expansion size, RNA foci, MBNL1 colocalization, and splicing defects in DM1 patient-derived myoblasts, on the one hand, and the clinical characteristics of the patients, on the other hand. We have obtained new pathophysiology data related to how DM1 might affect patient-derived myoblasts.

\section{Methods}

\section{Standard protocol approvals, registrations, and patient consents}

This study was approved (reference \# PI-15-009) by the Ethic Committee of the University Hospital Germans Trias i Pujol (Badalona, Spain) and was performed in agreement with the Declaration of Helsinki for Human Research. All participants signed a written informed consent to participate in the study.

\section{Participants}

Six patients were recruited for this study, with DM1 diagnosis confirmed in our laboratory by bidirectional triplet PCR, as previously described. ${ }^{7}$ Patient muscle biopsies were obtained from the left biceps brachialis $(\mathrm{n}=5)$ and vastus lateralis muscle $(\mathrm{n}=1)$. The control biopsies were obtained from the hand muscle abductor pollicis longus of healthy individuals (see supplemental data, links.lww.com/NXG/
A291, for more information on the participants and clinical data collection).

\section{Myoblast cultures}

We extracted muscle cells from the biopsy explants and placed them on culture plates between 2015 and 2016 in the cell culture room of our institution (see supplemental data, links.lww.com/ NXG/A291, for more information) and analyzed data from these myoblasts during 2018 and 2019 as described below.

\section{Expansion repeat sizing in myoblasts}

We determined CTG expansion size using long PCRsouthern blotting (see supplemental data, links.lww.com/ NXG/A291, for a detailed description of the protocol).

\section{Three-dimensional imaging of RNA foci and MBNL1}

To detect RNA foci and MBNL1, we performed fluorescence in situ hybridization and immunostaining. The protocol we used and the details of 3D imaging can be found in supplemental data, links.lww.com/NXG/A291.

\section{Alternative splicing analysis and DMPK expression}

We analyzed alternative splicing and DMPK expression with reverse transcription (RT) PCR and quantitative PCR (qPCR), respectively (see supplemental data, links.lww.com/NXG/ A291, for more information on the protocol and primers).

\section{Statistical analysis}

Details of the statistical analysis can be found in supplemental data, links.lww.com/NXG/A291.

\section{Data availability}

The data that support the findings of this study are available from the corresponding author on reasonable request.

\section{Results}

\section{Patients' phenotype}

We studied 6 patients with DM1-4 women and 2 menwith age at disease onset ranging from 15 to 48 years (table 1 ). Patients were unrelated except P3 and P4 (who were sisters). The majority of patients had cardiac problems, with 3 showing mild ECG alterations, one (P2) a structural cardiopathy (valvulopathy), and another one (P5) using a pacemaker. Half of the patients needed nocturnal mechanical ventilation, and the other 3 had mild changes in respiratory functional tests without actual clinical impairment. The muscular impairment status according to the Muscular Impairment Rating Scale was 
Table 1 Clinical data of patients with DM1

\begin{tabular}{|c|c|c|c|c|c|c|c|c|c|c|}
\hline $\begin{array}{l}\text { Patient with } \\
\text { DM1 }\end{array}$ & Sex & Age at onset (y) & $\begin{array}{l}\text { Biceps } \\
\text { MRC }\end{array}$ & Myotonia (s) & Cataracts & Cardiopathy & Spirometry & 6MWD (m) & MIRS & $\mathrm{mRS}$ \\
\hline P1 & $\mathrm{F}$ & $15^{a}$ & 4 & 0.52 & No & LAFB & Altered PFT & 348 & 4 & 2 \\
\hline P2 & M & 48 & 5 & 0.67 & Yes & Valvulopathy & NMV & 251 & 3 & 2 \\
\hline P3 & $\mathrm{F}$ & 36 & 5 & 0.73 & Yes & None & NMV & 368 & 2 & 1 \\
\hline P4 & $\mathrm{F}$ & 42 & 5 & 0.98 & Yes & $\begin{array}{l}\text { 1st-degree AV } \\
\text { block }\end{array}$ & NMV & 338 & 3 & 1 \\
\hline P5 & $\mathrm{F}$ & 27 & 4 & NP & Yes & Pacemaker & Altered PFT & NP & 4 & 4 \\
\hline P6 & M & 36 & 5 & 0.96 & No & LAFB & Altered PFT & 519 & 3 & 2 \\
\hline
\end{tabular}

Abbreviations: $6 \mathrm{MWD}$ = 6-minute walking distance; $\mathrm{AV}=$ atrioventricular; NP = not performed; LAFB = left anterior fascicular block; $\mathrm{mRS}=$ modified Rankin Scale; MIRS = Muscular Impairment Rating Scale; MRC = Medical Research Council Grade; NMV = nocturnal mechanical ventilation; PFT = pulmonary function tests. a It was not possible to determine the actual age at onset of patient P1, but since at the first visit (age 36 years), she had obvious signs that commonly appear in the early patient's life-including oval pallor and temporal atrophy-we considered that the disease onset occurred during adolescence.

variable, with P3 showing minimal signs of muscular impairment on exploration, P2, P4, and P6 presenting with distal weakness, and P1 and P5 with mild-to-moderate proximal weakness. Most patients were independent in activities of daily living (modified Rankin Scale [mRS] score 0-2), yet one (P5) had severely limitations (mRS score 4). P5 did not to do the 6-minute walking distance test or the myotonic evaluation because she died unexpectedly due to respiratory insufficiency at age 40 years.

\section{CTG expansion correlates with RNA foci}

We determine the CTG expansion size and the RNA foci and MBNL1 staining analyses in the same cells by dividing the cell lines in different pools. The CTG expansion size in DM1 myoblast cell lines ranged from 195 to 1568 CTG repeats (table 2).

For the staining of RNA foci and MBNL1, we studied 71 and 84 myoblasts from patients and controls, respectively. There was a high heterogeneity among DM1 myoblasts with regard to number of RNA foci. Thus, there was an average of 3 RNA foci (cytoplasmic and/or nuclear) per cell (range 0-6). On the other hand, there were no RNA foci in the control myoblasts (supplemental figure 1, links.lww.com/NXG/A298).

Heterogeneity was also found for the percentage of cells carrying RNA foci. Thus, 4 patients had RNA foci in $100 \%$ of their myoblasts, whereas P2 and P6 had RNA foci in $80 \%$ and $45 \%$ of myoblasts, respectively. Of interest, the cell lines from P2 and P6 were those carrying the lowest CTG repeat number (195 and 230, respectively). We found a strong positive correlation between CTG repeat number and (1) the average number of total (cytoplasmic + nuclear) RNA foci per myoblast (figure 1A), as well as with (2) the average number of nuclear RNA foci per myoblast $(r=0.830 ; 95 \%$ confidence interval [CI] 0.056-0.981).

RNA foci in DM1 myoblasts are mostly, but not only, intranuclear

RNA foci were mainly present in the nuclei of DM1 cells. Nevertheless, all 6 DM1 myoblast lines also showed RNA foci outside this organelle. The prevalence of cytoplasmic RNA

Table 2 CTG expansion size and 3D analysis data in DM1 myoblasts

\begin{tabular}{|c|c|c|c|c|c|c|c|c|c|}
\hline $\begin{array}{l}\text { Derived } \\
\text { DM1 cell } \\
\text { line }\end{array}$ & $\begin{array}{l}\text { CTG } \\
\text { repeats }\end{array}$ & $\begin{array}{l}\text { No. of } \\
\text { cells } \\
\text { analyzed }\end{array}$ & $\begin{array}{l}\text { Minimum } \\
\text { no. of RNA } \\
\text { foci/cell }\end{array}$ & $\begin{array}{l}\text { Maximum } \\
\text { no. of RNA } \\
\text { foci/cell }\end{array}$ & $\begin{array}{l}\text { RNA } \\
\text { foci/ } \\
\text { cell }\end{array}$ & $\begin{array}{l}\text { RNA foci } \\
\text { area } \\
\text { average } \\
\left(\mu \mathrm{m}^{2}\right)\end{array}$ & $\begin{array}{l}\% \text { of cells } \\
\text { containing } \\
\text { RNA foci }\end{array}$ & $\begin{array}{l}\% \text { RNA foci } \\
\text { in the } \\
\text { cytoplasm }\end{array}$ & $\begin{array}{l}\% \text { of cells containing } \\
\text { both nuclear and } \\
\text { cytoplasmic RNA foci }\end{array}$ \\
\hline P1 & 758 & 11 & 1 & 6 & 2.7 & 1.6 & 100 & 23 & 36 \\
\hline P2 & 195 & 10 & 0 & 5 & 1.8 & 0.7 & 80 & 6 & 10 \\
\hline P3 & 899 & 16 & 2 & 6 & 3.5 & 0.5 & 100 & 14 & 38 \\
\hline P4 & 1,568 & 11 & 2 & 6 & 4.4 & 0.3 & 100 & 8 & 45 \\
\hline P5 & 292 & 12 & 1 & 6 & 3.2 & 0.9 & 100 & 11 & 25 \\
\hline P6 & 230 & 11 & 0 & 5 & 2.3 & 0.2 & 45 & 4 & 9 \\
\hline
\end{tabular}

Abbreviation: DM1 = myotonic dystrophy type 1 . 


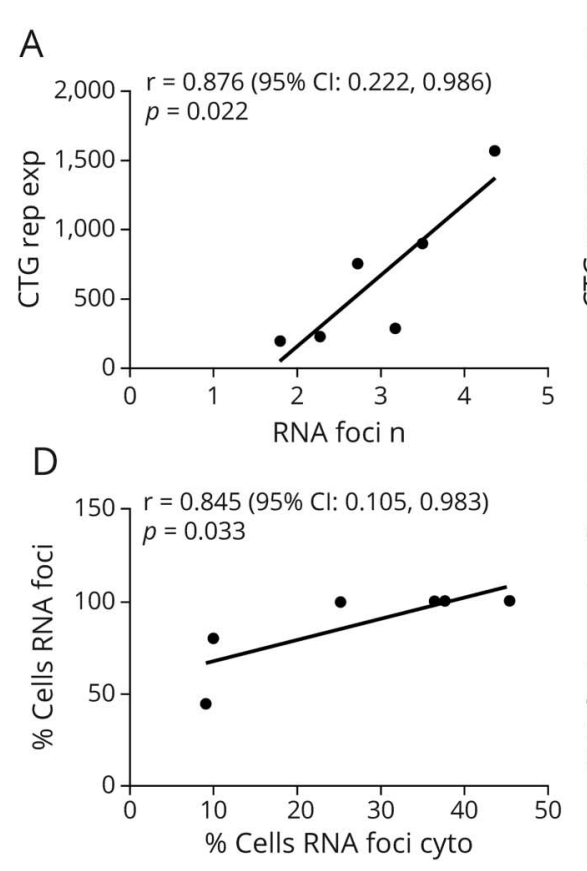

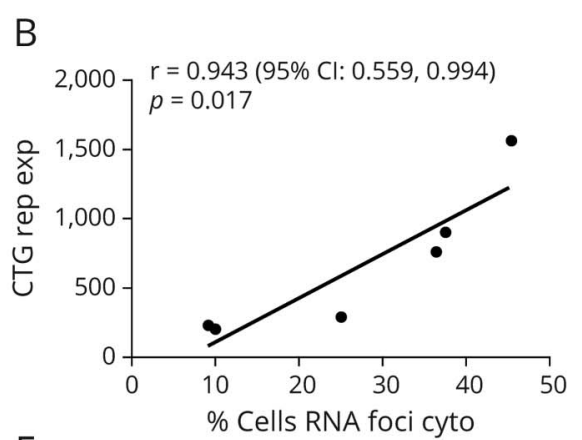

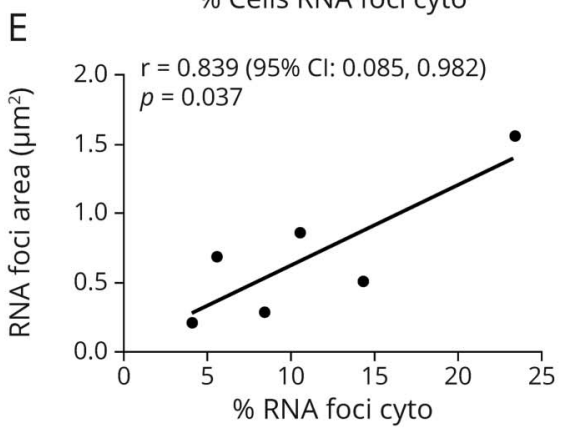

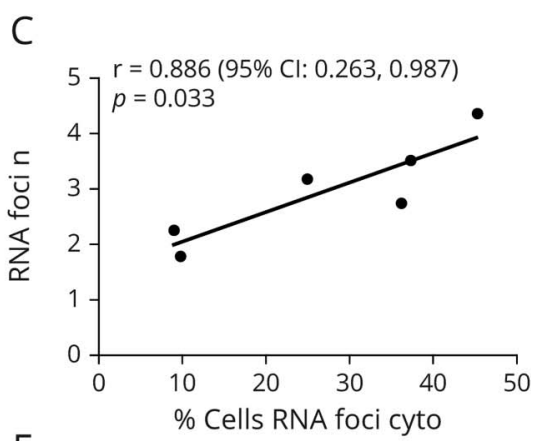

$\mathrm{F}$

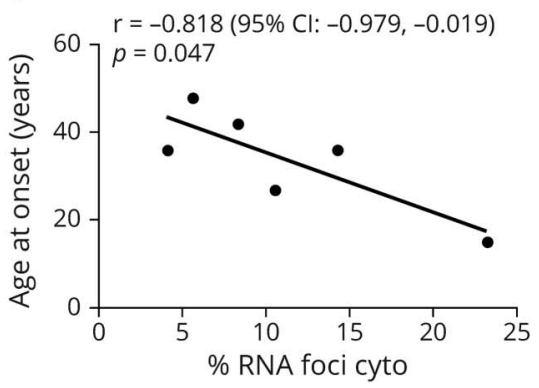

(A) Correlation between CTG repeat expansion and RNA foci number. The 95\% CI for the Pearson correlation coefficient was 0.222-0.986. (B) Correlation between CTG repeat expansion and percentage of cells presenting cytoplasmic RNA foci. The $95 \% \mathrm{CI}$ for the Pearson correlation coefficient was 0.559-0.994. (C) Correlation between RNA foci number and \% of cells presenting cytoplasmic RNA foci. The $95 \% \mathrm{CI}$ for the Pearson correlation coefficient was $0.263-0.987$. (D) Correlation between \% of cells presenting RNA foci and \% of cells presenting cytoplasmic RNA foci. The $95 \%$ CI for the Pearson correlation coefficient was 0.105-0.983. (E) Correlation between the RNA foci area $\left(\mu \mathrm{m}^{2}\right)$ and the presence of cytoplasmic RNA foci. The $95 \% \mathrm{Cl}$ for the Pearson correlation coefficient was 0.085-0.982. (F) Correlation between age at onset of the disease and the presence of cytoplasmic RNA foci. The $95 \% \mathrm{Cl}$ for the Pearson correlation coefficient was -0.979 to -0.019 . rep exp = repeat expansion; $n=$ number; cyto = cytoplasm.

foci was, however, heterogeneous-ranging from $4 \%$ to $23 \%$ of all RNA foci found (mean = 12\%) (table 2). The percentage of myoblasts showing cytoplasmic RNA foci also varied among the different DM1 patient lines, ranging from $10 \%$ to $45 \%$ of cells. On the other hand, there were no cells showing cytoplasmic-only RNA foci.

We found a strong, positive correlation between the number of CTG repeats and the percentage of cells with cytoplasmic RNA foci (figure 1B). We also found a positive correlation between the average total number (nuclear + cytoplasmic) of RNA foci per myoblast and the percentage of cells presenting RNA foci in the cytoplasm (figure 1C) and also between the percentage of DM1 myoblasts presenting RNA foci (nuclear and/or cytoplasmic) and the percentage of RNA foci in the cytoplasm (figure 1D). We further analyzed the area occupied by RNA foci (table 2) and found a positive correlation between this variable and the presence of cytoplasmic foci (figure 1E). Thus, those cell lines that contained RNA foci with larger areas had more foci in the cytoplasm.

\section{Higher number of cytoplasmic RNA foci is associated with an earlier disease onset}

When analyzing the relationship between the 3D molecular findings and the phenotype of patients with DM1, we found that the number of cytoplasmic RNA foci was inversely related to the age at disease onset (figure $1 \mathrm{~F}$ ).

\section{RNA foci only represent a small fraction of the total nucleus volume}

The portion of the total nuclear dimension occupied by RNA foci was analyzed by determining the volume of all the RNA foci inside the nucleus and by comparing this variable with the total nuclear volume. RNA foci occupied $0.34 \%-0.53 \%$ of the total nuclear volume in DM1 myoblasts.

\section{Trapped MBNL1 in RNA foci represent a negligible fraction of total MBNL1 expression}

Given the main role that MBNL1 plays in DM1 disease, we aimed to analyze the trapping of this protein in the RNA foci. MBNL1 protein was present in control and DM1 myoblasts. In all analyzed myoblasts, MBNL1 was located both in the nucleus and in the cytoplasm (figure 2, B and E). Colocalization of RNA foci together with MBNL1 was found in all DM1 patients' lines. The trapped MBNL1 was not only found in the nucleus (figure 2, A-C), but also in the cytoplasm (figure 2, D-F), representing $9 \%$ of the total cellular colocalization (Video 1). Trapped MBNL1 represented less than $1 \%$ of the total MBNL1 expression in DM1 myoblasts.

\section{RNA foci are associated with DMPK transcripts} As RNA foci are the product of DMPK gene transcription, we aimed to analyze DMPK transcripts in our myoblast cell lines. To this end, we chose qPCR as it is a more sensitive technique than RT-PCR and used a probe that was located outside the 

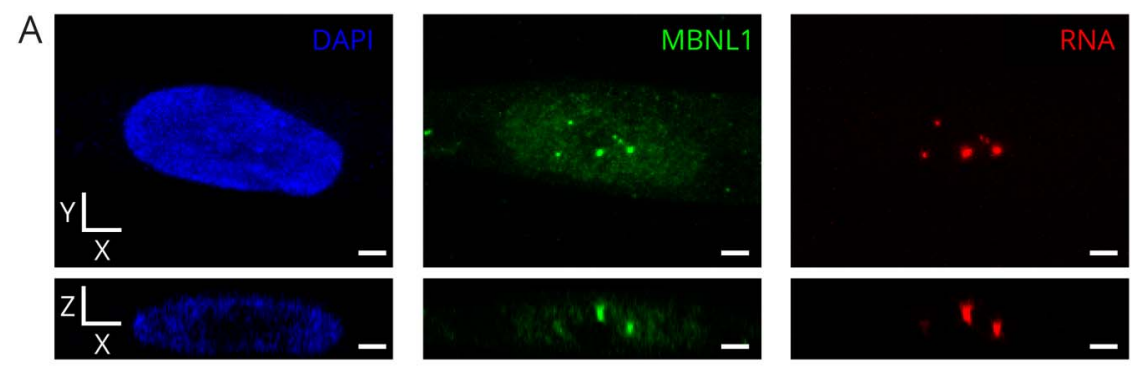

$\mathrm{B}$

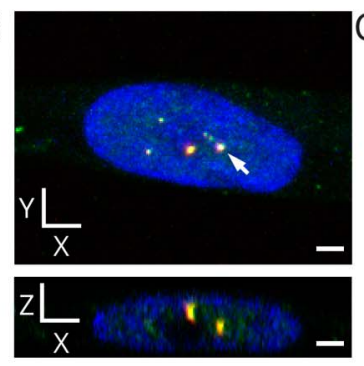

D
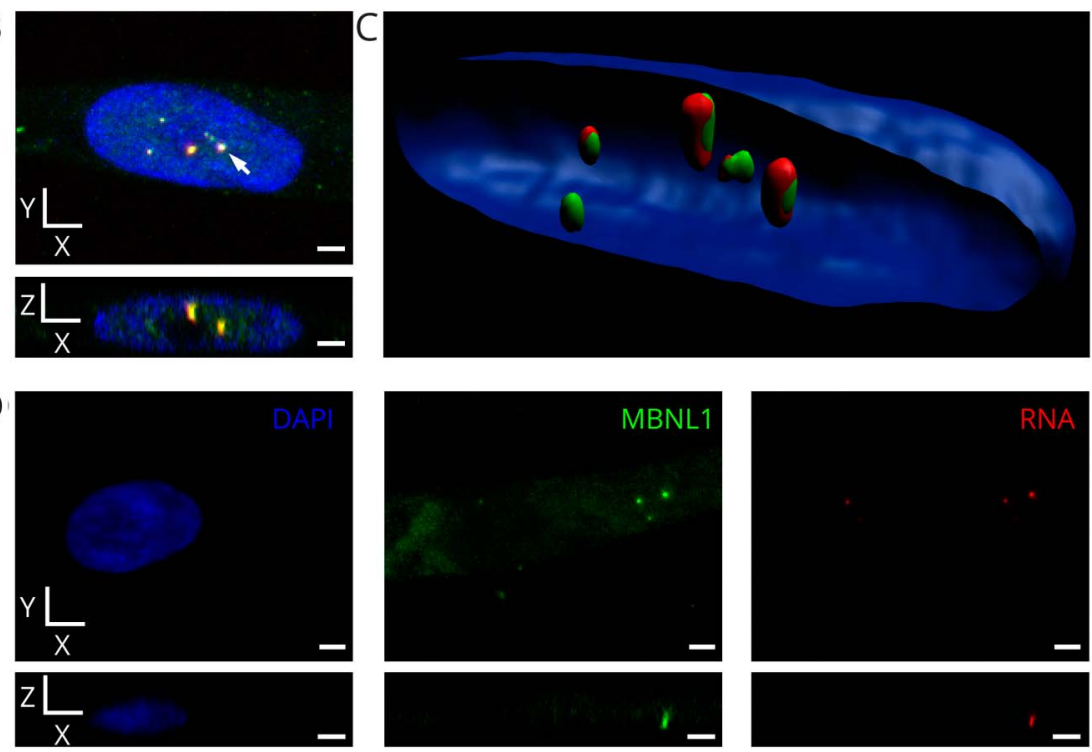

E
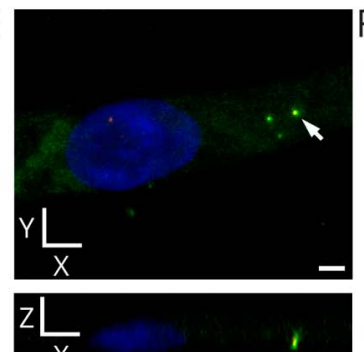

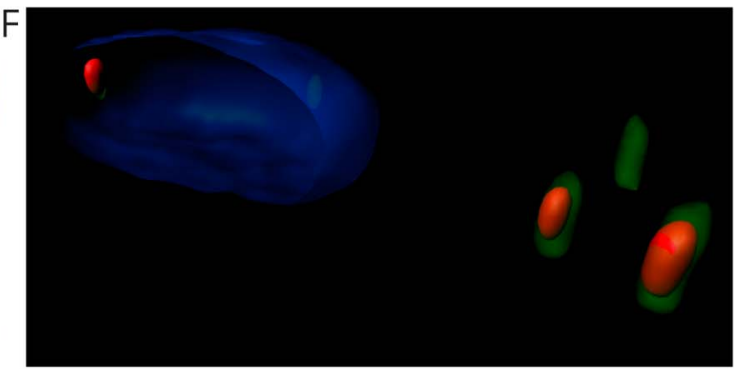

MBNL1 protein (green), RNA foci (red), nucleus (blue). Scale bars: $2.5 \mu \mathrm{m}$. (A) XY and XZ volume slices of individual channels corresponding to nucleus (blue), MBNL1 protein (green), and RNA foci (red). DM1 myoblast showing the nuclear colocalization between the RNA foci and the MBNL1 protein. (B) Merged image of $X Y$ and $X Z$ volume slices of representative nuclear colocalization between RNA foci and MBNL1 protein in DM1 myoblast. White arrow indicates a single RNA foci aggregate colocalizing with MBNL1 protein. (C) Isosurface rendering of nuclear colocalization between RNA foci and MBNL1 protein in DM1 myoblasts. (D) $X Y$ and $X Z$ volume slices of individual channels corresponding to nucleus (blue), MBNL1 protein (green), and RNA foci (red). DM1 myoblast showing the cytoplasmic colocalization between the RNA foci and the MBNL1 protein. (E) Merged image of $X Y$ and $X Z$ volume slices of representative cytoplasmic colocalization between RNA foci and MBNL1 protein in DM1 myoblast. White arrow indicates a single RNA foci aggregate colocalizing with MBNL1 protein. (F) Isosurface rendering of cytoplasmic colocalization between RNA foci and MBNL1 protein in DM1 myoblasts. MBNL1 = muscleblind like 1 .
CTG repeat for detecting expression of both wild-type and expanded DMPK alleles. We did not find significant differences between the $D M P K$ expression of patients and controls myoblasts (figure 3A). In turn, we found a positive correlation between $D M P K$ expression and (1) total (nuclear and/or cytoplasmic) RNA foci number $(r=0.967$ [95\% CI 0.079-0.999], $p=0.033$ ), as well as with the RNA foci that were present in the nucleus only $(r=0.993$ [95\% CI 0.682-0.999], $p=0.008$ ).

\section{Absence of DM1 alternative splicing patterns in DM1 myoblasts}

To study the extent to which was alternative splicing affected in DM1 myoblasts, we analyzed the expression of inclusion and exclusion isoforms-MBNL1 exon 7, INSR exon 11, and ATP2A1 exon 22-that have been previously reported to be altered in DM1. ${ }^{4,8,9}$ No differences were found between controls and patients in the expression of MBNL1 or ATP2A1 isoforms. However, the expression levels of the INSR exon 11 exclusion isoform-the most expressed isoform in some DM1 models - showed a tendency of higher expression in controls than in patients (figure 3B).

\section{Discussion}

We studied the quantity and distribution of RNA foci and MBNL1 protein in DM1 patient-derived myoblasts using a novel 3D imaging approach. In addition, in the same myoblast cultures, we measured CTG expansion, DMPK expression, and some alternative splicing events. All the molecular data were correlated with the clinical characteristics of the patients with DM1. Thus, although more research is needed, the $3 \mathrm{D}$ 

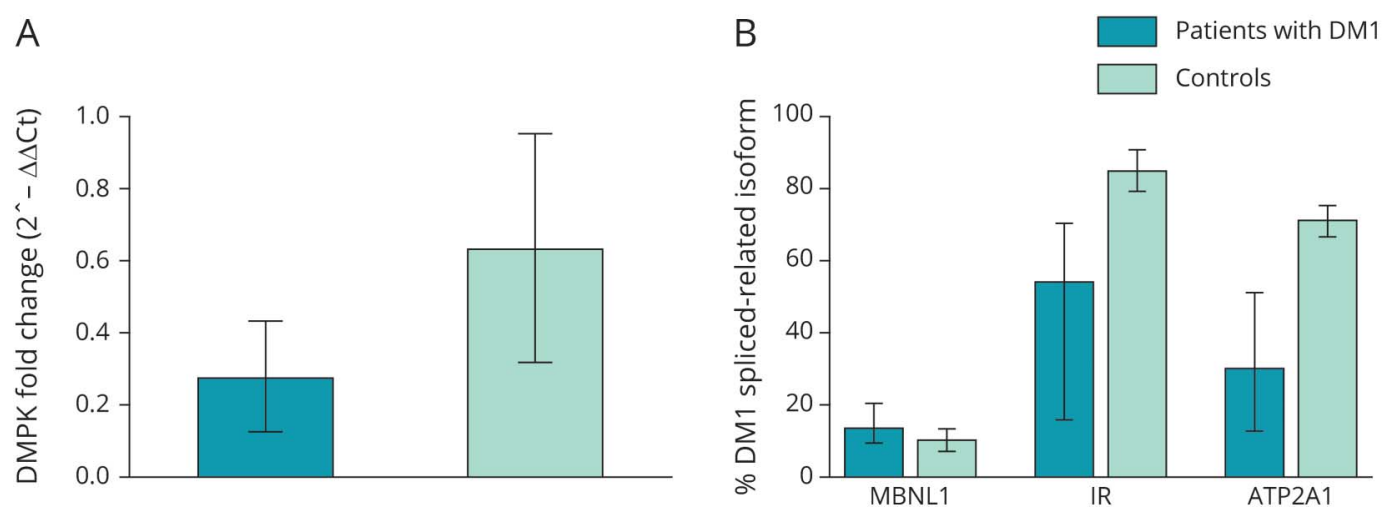

Data are mean \pm SD. (A) qDMPK expression in patients with DM1 vs controls. (B) Percentage of the DM1 spliced-related isoform in patients with DM1 compared with controls for MBNL1, IR, and ATP2A1 transcripts measured with RT-PCR. MBNL1 and ATP2A1 showed no significant differences, whereas IR showed a tendency of higher expression in controls compared with patients $(p=0.057$; effect size [Cohen $d]=1.83)$. DMPK = dystrophia myotonica protein; IR = insulin receptor; MNBL1 = muscleblind like 1.

method we used appears as a potential tool to identify potential associations between molecular alterations and clinical manifestations in patients with DM1.

Our results indicate that the number of RNA foci per DM1 myoblast is regulated by the CTG expansion length. A previous study showed that RNA foci number differed between patients with DM1 carrying $<500$ or $>1000$ CTG repeats, respectively. ${ }^{10}$ In this regard, we have analyzed patients carrying CTG expansions within the 500-1,000 range, with RNA foci related to CTG repeat number. On the other hand, our data indicate that there are a small number of RNA foci per DM1 myoblast, averaging only 3 per cell (range 0-6), which is consistent with the findings of previous research in muscle tissue. $^{3,10-12}$

Of interest, not all the DM1 myoblasts derived from the same patient had RNA foci. Two lines of patient-derived myoblasts who carried the shorter expansions showed RNA foci only in $40 \%$ and $80 \%$ of the cells. Thus, our results suggest that CTG expansion not only regulates the amount of RNA foci per myoblast but also the number of myoblasts presenting RNA foci. In this regard, previous research has suggested that RNA foci can undergo dynamic changes during the cell cycle ${ }^{13}$ and travel from one cell to another. ${ }^{14}$ Thus, although we cannot discard a certain effect of the cell cycle phase on our results, we tried to minimize this potential confounder by seeding the different DM1 myoblast cell lines following a well-defined protocol and using consistently the same treatment method. Based on the expansion sizes that we studied, DM1 myoblasts carrying expansions close to-or larger than-300 CTG repeats would carry RNA foci in all their cells. To study whether 300 CTG repeats is an actual threshold for all patients with DM1 will require a challenging 3D study in muscle tissue of patients with DM1.

We found both nuclear and cytoplasmic RNA foci. Although we found myoblasts with cytoplasmic RNA foci in all the
DM1 cell lines that we studied, no myoblast presented cytoplasmic-only RNA foci. CTG expansion size appears to regulate the formation of cytoplasmic RNA foci. Thus, larger CTG expansions will produce a higher number of nuclear foci, and therefore, more cells will contain cytoplasmic foci because the latter only appeared in association with nuclear foci. The presence and origin of cytoplasmic foci have not yet been studied in depth. Some authors have suggested that cytoplasmic RNA foci are a product of the cell cycle as well as of the breakdown of the nuclear membrane and as such are more likely to appear in dividing cells. ${ }^{13}$ However, a study in an animal model of DM1 expressing CTG expansions in the heart tissue found RNA foci exclusively in the cytoplasm of cardiomyocytes, which are highly differentiated, nondividing cells. ${ }^{15}$ On the other hand, our results show that cytoplasmic RNA foci colocalize with MBNL1. The role of cytoplasmic foci and whether they have a toxic effect should be studied in future research.

RNA foci represent less than $0.6 \%$ of the total nuclear volume in DM1 myoblasts. Although researchers in the DM1 area are aware of the small size of RNA foci and of the difficulty to identify them under the microscope by naked eye, the data presented here add some information on the impact that RNA foci have on the nuclear volume. In addition, when analyzing the area of RNA foci in relation to other molecular findings, we observed a correlation with the number of cytoplasmic foci. The fact that scarce data are currently available on cytoplasmic RNA foci makes it difficult to interpret our results. However, as previously described by other authors, ${ }^{16}$ RNA foci can fuse or divide randomly with no apparent or known purpose.

Our analysis of MBNL1 revealed that the sequestration of this protein inside RNA foci represents less than $1 \%$ of the total MBNL1 myoblast expression. Although there are studies showing the pathologic role of MBNL1 in DM1, ${ }^{17-21}$ our 
results are consistent with a previous study by Coleman et al. ${ }^{22}$ reporting that only a small proportion of MBNL1 protein $(0.2 \%)$ was sequestered by RNA foci in DM1 lens epithelial cells. The study by Coleman and coworkers also showed that MBNL1 can freely travel from the nucleus to the cytoplasm or from the cytoplasm to the nucleus depending on the transcriptional levels and cell requirements. In this context, the low values of sequestration of MBNL1 would suggest that this phenomenon plays only a minor role in the pathophysiology of the disease, as $99 \%$ of total MBNL1 expression is free and DM1 myoblasts showed a distribution pattern similar to that of control myoblasts.

The levels of DMPK expression were related to the number of RNA foci per cell. This was an expected finding: indeed, if there are more RNA foci inside a cell, theoretically there should also be more DMPK, as for both RNA foci and DMPK determination, we used a technique, qPCR, which allows detecting expanded as well as wild-type alleles. How DMPK expression is affected in DM1 remains to be determined. $D M P K$ expression levels have been analyzed in several studies with inconclusive or contradictory results. Some studies found that DMPK transcripts were increased in myotubes derived from patients with $\mathrm{DM} 1{ }^{23}$ but other authors found the opposite result. ${ }^{10,24}$ In this regard, heterogeneity among studies with regard to assessment techniques and patient characteristics limits the ability to gain insight into the alteration of DMPK expression in DM1.

We did not find the expected altered DM1 splicing when analyzing IR, ATP2A1, and MBNL1 transcripts. As mentioned above, the trapped MBNL1 in RNA foci was a minor event in DM1 myoblasts, and thus, the cascade of molecular pathomechanisms in which the splicing alteration occurs due to MBNL1 protein sequestration does not seem to play a relevant role. These results could also be explained by the fact that the expression of the aforementioned aberrant isoforms is related to developmental stages, ${ }^{4,9}$ and because we used undifferentiated cells (i.e., myoblasts), the expression pattern should differ from the pattern of fully differentiated myotubes, and especially of skeletal muscle fibers.

Our results indicate that an earlier age at disease onset is associated with a higher number of cytoplasmic RNA foci. By contrast, the age at onset was not correlated with the number of CTG repeats or RNA foci per myoblast or to DMPK expression levels. Several studies ${ }^{25-28}$ have analyzed the possible association between CTG expansion size and the different DM1-related symptoms, but CTG instability adds heterogeneity to the disease, which further complicates to establish these associations.

Our study is limited by the low number of myoblast cell lines studied and by the complexity of 3D molecular imaging at the single cell level, which is a highly time-consuming approach. While keeping this limitation in mind, we were able to evaluate the molecular pathologic cascade in 6 patients with DM1 with different clinical manifestations of this disease.
Our 3D imaging study allowed us to analyze the role of potential DM1 players using a novel approach. Thus, our results would indicate that CTG expansion determines the number of RNA foci per myoblast and of myoblasts that contain RNA foci, as well as the appearance of cytoplasmic foci. An additional finding is that RNA foci only represent a small-and in fact negligible-part of the total nucleus volume and the sequestration of MBNL1 is an infrequent event. Thus, no DM1 splicing alterations were found. The $D M P K$ expression levels are related to the number of RNA foci found per myoblast. Last, we found that cytoplasmic RNA foci are inversely related to the age at onset of the patients with DM1 studied. Cytoplasmic RNA foci should be considered in future studies because the role of these molecules in the pathobiology of DM1 needs to be clearly elucidated.

\section{Acknowledgment}

The authors gratefully acknowledge the participants in this research and other researchers in the myotonic dystrophy type I field for their insightful advice regarding data presented in the present research work.

\section{Study funding}

The research of G. Nogales-Gadea, A. Ramos-Fransi, and A. Lucia is funded by Instituto de Salud Carlos III (grant numbers PI15/01756, PI15/00558, and PI18/00713) and cofinanced by Fondos FEDER. G. Nogales-Gadea is supported by a Miguel Servet research contract (ISCIII CD14/00032, ISCIII CPII19/00021, and FEDER) and by a Trampoline Grant \#21108 from AFM Telethon. A. Ballester-Lopez is funded by an FI Agaur fellowship ref. FI_B 01090 and SGR 1520 (GRC) Generalitat de Catalunya. E. Koehorst is funded by the La Caixa Foundation (ID 100010434), fellowship code LCF/BQ/IN18/11660019, cofunded by the European Union's Horizon 2020 research and innovation program under the Marie Skłodowska-Curie grant agreement no. 713673. I. Linares-Pardo is funded by CP14/00032 and SGR 1520 (GRC) Generalitat de Catalunya. J. Núñez-Manchón was funded by AFM Telethon Trampoline Grant \#21108. G. Lucente was supported by a Rio Hortega contract (ISCIII CM16/00016 and FEDER). J. Chojnacki is supported by European Union's Horizon 2020 research and innovation program under the Marie Skłodowska-Curie grant agreement no. 793830 . The funding bodies had no role in the design of the study and collection, analysis, and interpretation of data.

\section{Disclosure}

A. Ballester-Lopez is funded by an FI Agaur fellowship FI_B 01090 and SGR 1520 (GRC) Generalitat de Catalunya. J. Núñez-Manchón is funded by AFM Telethon Trampoline Grant \#21108. E Koehorst is funded by the La Caixa Foundation (ID 100010434), fellowship code LCF/BQ/IN18/ 11660019, cofunded by the European Union's Horizon 2020 research and innovation program under the Marie Skłodowska-Curie grant agreement no. 713673. I. LinaresPardo is funded by CP14/00032 and SGR 1520 (GRC) 
Generalitat de Catalunya. M. Almendrote reports no disclosures relevant to the manuscript. G. Lucente is supported by a Rio Hortega contract (ISCIII CM16/00016 and FEDER). N. Guanyabens, M. Lopez-Osias, A. Suárez-Mesa, S. Hanick, and J. Chojnack report no disclosures relevant to the manuscript. A. Lucia declares grants from the Spanish government granting agency Instituto de Salud Carlos III, Madrid, Spain. G. Pintos-Morell reports personal honoraria from ShireTakeda, Amicus, and Sanofi-Genzyme, outside the submitted work. J. Coll-Cantí, A. Martínez-Piñeiro, and A. Ramos-Fransi report no disclosures relevant to the manuscript. G. NogalesGadea declares grants from Instituto de Salud Carlos III, Madrid, Spain, and AFM Telethon, France. G. Nogales-Gadea is supported by a Miguel Servet research contract (ISCIII CD14/00032, CPII19/00021, and FEDER). Go to Neurology.org/NG for full disclosures.

\section{Publication history}

Received by Neurology: Genetics February 21, 2020. Accepted in final form June 5, 2020.

Appendix Authors

\begin{tabular}{|c|c|c|}
\hline Name & Location & Contribution \\
\hline $\begin{array}{l}\text { Alfonsina } \\
\text { Ballester- } \\
\text { Lopez, MSc }\end{array}$ & $\begin{array}{l}\text { Institut d'Investigació en } \\
\text { Ciències de la Salut } \\
\text { Germans Trias i Pujol, } \\
\text { Badalona, Spain }\end{array}$ & $\begin{array}{l}\text { Data collection; } \\
\text { acquisition and analysis; } \\
\text { and drafting of the } \\
\text { manuscript }\end{array}$ \\
\hline $\begin{array}{l}\text { Judit Núñez- } \\
\text { Manchón, } \\
\text { MSc }\end{array}$ & $\begin{array}{l}\text { Institut d'Investigació en } \\
\text { Ciències de la Salut } \\
\text { Germans Trias i Pujol, } \\
\text { Badalona, Spain }\end{array}$ & $\begin{array}{l}\text { Data acquisition and } \\
\text { drafting of the manuscript }\end{array}$ \\
\hline $\begin{array}{l}\text { Emma } \\
\text { Koehorst, } \\
\text { MSc }\end{array}$ & $\begin{array}{l}\text { Institut d'Investigació en } \\
\text { Ciències de la Salut } \\
\text { Germans Trias i Pujol, } \\
\text { Badalona, Spain }\end{array}$ & $\begin{array}{l}\text { Revision of the } \\
\text { manuscript }\end{array}$ \\
\hline $\begin{array}{l}\text { lan Linares- } \\
\text { Pardo }\end{array}$ & $\begin{array}{l}\text { Institut d'Investigació en } \\
\text { Ciències de la Salut } \\
\text { Germans Trias i Pujol, } \\
\text { Badalona, Spain }\end{array}$ & $\begin{array}{l}\text { Collecting and acquisition } \\
\text { of the data }\end{array}$ \\
\hline $\begin{array}{l}\text { Miriam } \\
\text { Almendrote, } \\
\text { MD }\end{array}$ & $\begin{array}{l}\text { Hospital Universitari } \\
\text { Germans Trias i Pujol, } \\
\text { Badalona, Barcelona, } \\
\text { Spain }\end{array}$ & $\begin{array}{l}\text { Collecting the clinical data } \\
\text { and revision of the } \\
\text { manuscript }\end{array}$ \\
\hline $\begin{array}{l}\text { Giuseppe } \\
\text { Lucente, MD }\end{array}$ & $\begin{array}{l}\text { Hospital Universitari } \\
\text { Germans Trias i Pujol, } \\
\text { Badalona, Barcelona, } \\
\text { Spain }\end{array}$ & $\begin{array}{l}\text { Revision of the } \\
\text { manuscript }\end{array}$ \\
\hline $\begin{array}{l}\text { Nicolau } \\
\text { Guanyabens, } \\
\text { MD }\end{array}$ & $\begin{array}{l}\text { Hospital Universitari } \\
\text { Germans Trias i Pujol, } \\
\text { Badalona, Barcelona, } \\
\text { Spain }\end{array}$ & Collecting the clinical data \\
\hline $\begin{array}{l}\text { Marta Lopez- } \\
\text { Osias, BSc }\end{array}$ & $\begin{array}{l}\text { Institut d'Investigació en } \\
\text { Ciències de la Salut } \\
\text { Germans Trias i Pujol, } \\
\text { Badalona, Spain }\end{array}$ & Data acquisition \\
\hline $\begin{array}{l}\text { Adrián } \\
\text { Suárez-Mesa, } \\
\text { MSc }\end{array}$ & $\begin{array}{l}\text { Institut d'Investigació en } \\
\text { Ciències de la Salut } \\
\text { Germans Trias i Pujol, } \\
\text { Badalona, Spain }\end{array}$ & $\begin{array}{l}\text { Data acquisition and } \\
\text { revision of the manuscript }\end{array}$ \\
\hline
\end{tabular}

Appendix (continued)

\begin{tabular}{|c|c|c|}
\hline Name & Location & Contribution \\
\hline $\begin{array}{l}\text { Shaliza Ann } \\
\text { Hanick, MSc }\end{array}$ & $\begin{array}{l}\text { Institut d'Investigació en } \\
\text { Ciències de la Salut } \\
\text { Germans Trias i Pujol, } \\
\text { Badalona, Spain }\end{array}$ & $\begin{array}{l}\text { Data acquisition and } \\
\text { revision of the manuscript }\end{array}$ \\
\hline $\begin{array}{l}\text { Jakub } \\
\text { Chojnacki, } \\
\text { PhD }\end{array}$ & $\begin{array}{l}\text { IrsiCaixa AIDS Research } \\
\text { Institute, Badalona, Spain }\end{array}$ & Image analysis \\
\hline $\begin{array}{l}\text { Alejandro } \\
\text { Lucia, MD, } \\
\text { PhD }\end{array}$ & $\begin{array}{l}\text { Universidad Europea de } \\
\text { Madrid and Instituto de } \\
\text { Investigación Hospital } 12 \\
\text { de Octubre (i+12), Madrid, } \\
\text { Spain }\end{array}$ & $\begin{array}{l}\text { Analysis of the data and } \\
\text { revision of the manuscript }\end{array}$ \\
\hline $\begin{array}{l}\text { Guillem } \\
\text { Pintos- } \\
\text { Morell, MD, } \\
\text { PhD }\end{array}$ & $\begin{array}{l}\text { Hospital Universitari Vall } \\
\text { d'Hebron, Barcelona, Spain }\end{array}$ & $\begin{array}{l}\text { Revision of the } \\
\text { manuscript }\end{array}$ \\
\hline $\begin{array}{l}\text { Jaume Coll- } \\
\text { Cantí, MD, } \\
\text { PhD }\end{array}$ & $\begin{array}{l}\text { Hospital Universitari } \\
\text { Germans Trias i Pujol, } \\
\text { Badalona, Barcelona, } \\
\text { Spain }\end{array}$ & $\begin{array}{l}\text { Revision of the } \\
\text { manuscript }\end{array}$ \\
\hline $\begin{array}{l}\text { Alicia } \\
\text { Martínez- } \\
\text { Piñeiro, MD }\end{array}$ & $\begin{array}{l}\text { Hospital Universitari } \\
\text { Germans Trias i Pujol, } \\
\text { Badalona, Barcelona, } \\
\text { Spain }\end{array}$ & $\begin{array}{l}\text { Revision of the } \\
\text { manuscript }\end{array}$ \\
\hline $\begin{array}{l}\text { Alba Ramos- } \\
\text { Fransi, MD, } \\
\text { PhD }\end{array}$ & $\begin{array}{l}\text { Hospital Universitari } \\
\text { Germans Trias i Pujol, } \\
\text { Badalona, Barcelona, } \\
\text { Spain }\end{array}$ & $\begin{array}{l}\text { Clinical data collection } \\
\text { and drafting of the } \\
\text { manuscript }\end{array}$ \\
\hline $\begin{array}{l}\text { Gisela } \\
\text { Nogales- } \\
\text { Gadea, PhD }\end{array}$ & $\begin{array}{l}\text { Institut d'Investigació en } \\
\text { Ciències de la Salut } \\
\text { Germans Trias i Pujol, } \\
\text { Badalona, Spain }\end{array}$ & $\begin{array}{l}\text { Design of the study and } \\
\text { drafting of the manuscript }\end{array}$ \\
\hline
\end{tabular}

\section{References}

1. Brook JD, McCurrach ME, Harley HG, et al. Molecular basis of myotonic dystrophy: expansion of a trinucleotide (CTG) repeat at the 3' end of a transcript encoding a protein kinase family member. Cell 1992;69:385.

2. Tian B, White RJ, Xia T, et al. Expanded CUG repeat RNAs form hairpins that activate the double-stranded RNA-dependent protein kinase PKR. RNA 2000;6:79-87.

3. Taneja KL, McCurrach M, Schalling M, Housman D, Singer RH. Foci of trinucleotide repeat transcripts in nuclei of myotonic dystrophy cells and tissues. J Cell Biol 1995; 128:995-1002.

4. Dansithong W, Paul S, Comai L, Reddy S. MBNL1 is the primary determinant of focus formation and aberrant insulin receptor splicing in DM1.J Biol Chem 2005;280: 5773-5780.

5. Schara U, Schoser BGH. Myotonic dystrophies type 1 and 2: a summary on current aspects. Semin Pediatr Neurol 2006;13:71-79.

6. Konieczny P, Stepniak-Konieczna E, Sobczak K. MBNL expression in autoregulatory feedback loops. RNA Biol 2018;15:1-8.

7. Radvansky J, Ficek A, Minarik G, Palffy R, Kadasi L. Effect of unexpected sequence interruptions to conventional PCR and repeat primed PCR in myotonic dystrophy type 1 testing. Diagn Mol Pathol 2011;20:48-51.

8. Lin X, Miller JW, Mankodi A, et al. Failure of MBNL1-dependent post-natal splicing transitions in myotonic dystrophy. Hum Mol Genet 2006;15:2087-2097.

9. Hino SI, Kondo S, Sekiya $\mathrm{H}$, et al. Molecular mechanisms responsible for aberrant splicing of SERCA1 in myotonic dystrophy type 1. Hum Mol Genet 2007;16: 2834-2843.

10. Botta A, Rinaldi F, Catalli C, et al. The CTG repeat expansion size correlates with the splicing defects observed in muscles from myotonic dystrophy type 1 patients. J Med Genet 2008;45:639-646.

11. Mankodi A, Teng-Umnuay P, Krym M, Henderson D, Swanson M, Thornton CA. Ribonuclear inclusions in skeletal muscle in myotonic dystrophy types 1 and 2. Ann Neurol 2003;54:760-768

12. Gudde AEEG, González-Barriga A, van den Broek WJAA, Wieringa B, Wansink DG. A low absolute number of expanded transcripts is involved in myotonic dystrophy type 1 manifestation in muscle. Hum Mol Genet 2016;25:1648-1662.

13. Xia G, Ashizawa T. Dynamic changes of nuclear RNA foci in proliferating DM1 cells. Histochem Cell Biol 2015;143:557-564. 
14. Mondragon-Gonzalez R, Azzag K, Selvaraj S, Yamamoto A, Perlingeiro RCR Transplantation studies reveal internuclear transfer of toxic RNA in engrafted muscles of myotonic dystrophy 1 mice. EBioMedicine 2019;47:553-562.

15. Dansithong W, Wolf CM, Sarkar P, et al. Cytoplasmic CUG RNA foci are insufficien to elicit key DM1 features. PLoS One 2008;3:e3968.

16. Querido E, Gallardo F, Beaudoin M, Ménard C, Chartrand P. Stochastic and reversible aggregation of mRNA with expanded CUG-triplet repeats. J Cell Sci 2011 124:1703-1714.

17. Ho TH, Charlet-B N, Poulos MG, Singh G, Swanson MS, Cooper TA. Muscleblind proteins regulate alternative splicing. EMBO J 2004;23:3103-3112.

18. Kanadia RN, Johnstone KA, Mankodi A, et al. A muscleblind knockout model for myotonic dystrophy. Science 2003;302:1978-1980.

19. Kino Y, Washizu C, Oma Y, et al. MBNL and CELF proteins regulate alternative splicing of the skeletal muscle chloride channel CLCN1. Nucleic Acids Res 2009; 37:6477-6490.

20. Klinck R, Fourrier A, Thibault P, et al. RBFOX1 cooperates with MBNL1 to control splicing in muscle, including events altered in myotonic dystrophy type 1. PLoS One 2014;9:18-21.

21. Sellier C, Cerro-Herreros E, Blatter M, et al. RbFOX1/MBNL1 competition for CCUG RNA repeats binding contributes to myotonic dystrophy type 1 /type 2 differences. Nat Commun 2018;9:1-15.
22. Coleman SM, Prescott AR, Sleeman JE. Transcriptionally correlated subcellular dynamics of MBNL1 during lens development and their implication for the molecular pathology of myotonic dystrophy type 1. Biochem J 2014;458:267-280.

23. Bhagwati S, Ghatpande A, Leung B. Normal levels of DM RNA and myotonin protein kinase in skeletal muscle from adult myotonic dystrophy (DM) patients. Biochim Biophys Acta - Mol Basis Dis 1996;1317:155-157.

24. Fu YH, Friedman DL, Richards S, et al. Decreased expression of myotonin-protein kinase messenger RNA and protein in adult form of myotonic dystrophy. Science 1993;260:235-238

25. Panaite PA, Kuntzer T, Gourdon G, Barakat-Walter I. Respiratory failure in a mouse model of myotonic dystrophy does not correlate with the CTG repeat length. Respir Physiol Neurobiol 2013;189:22-26.

26. Hamshere MG, Harley H, Harper P, Brook JD, Brookfield JFY. Myotonic dystrophy: the correlation of (CTG) repeat length in leucocytes with age at onset is significant only for patients with small expansions. J Med Genet 1999;36:59-61.

27. Aldenbratt A, Lindberg C, Svensson MK. Reduced renal function in patients with Myotonic Dystrophy type 1 and the association to CTG expansion and other potential risk factors for chronic kidney disease. Neuromuscul Disord 2017;27:1038-1042.

28. Zatz M, Passos-Bueno MR, Cerqueira A, Marie SK, Vainzof M, Pavanello RC. Analysis of the CTG repeat in skeletal muscle of young and adult myotonic dystrophy patients: when does the expansion occur? Hum Mol Genet 1995;4 $401-406$ 


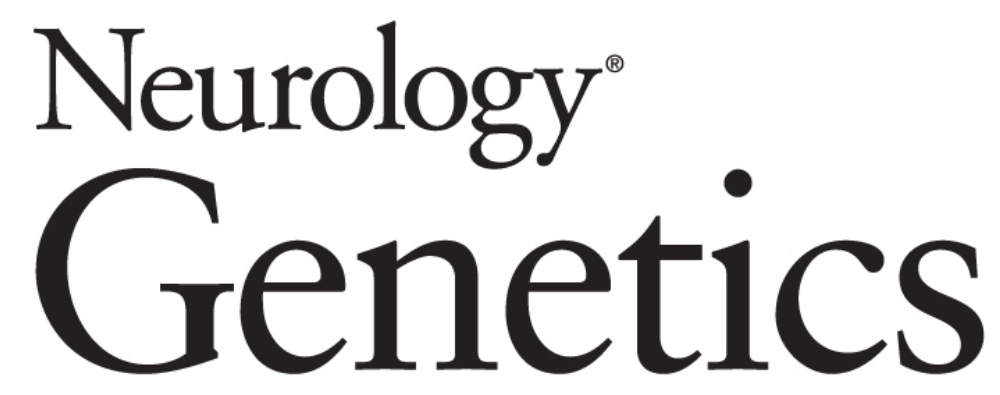

\section{Three-dimensional imaging in myotonic dystrophy type 1: Linking molecular alterations with disease phenotype \\ Alfonsina Ballester-Lopez, Judit Núñez-Manchón, Emma Koehorst, et al. \\ Neurol Genet 2020;6; \\ DOI 10.1212/NXG.0000000000000484}

\section{This information is current as of July 21, 2020}

Updated Information \& Services

References

Permissions \& Licensing

Reprints including high resolution figures, can be found at: http://ng.neurology.org/content/6/4/e484.full.html

This article cites 28 articles, 10 of which you can access for free at: http://ng.neurology.org/content/6/4/e484.full.html\#\#ref-list-1

Information about reproducing this article in parts (figures,tables) or in its entirety can be found online at:

http://ng.neurology.org/misc/about.xhtml\#permissions

Information about ordering reprints can be found online: http://ng.neurology.org/misc/addir.xhtml\#reprintsus

Neurol Genet is an official journal of the American Academy of Neurology. Published since April 2015, it is an open-access, online-only, continuous publication journal. Copyright Copyright $\odot 2020$ The Author(s). Published by Wolters Kluwer Health, Inc. on behalf of the American Academy of Neurology.. All rights reserved. Online ISSN: 2376-7839.

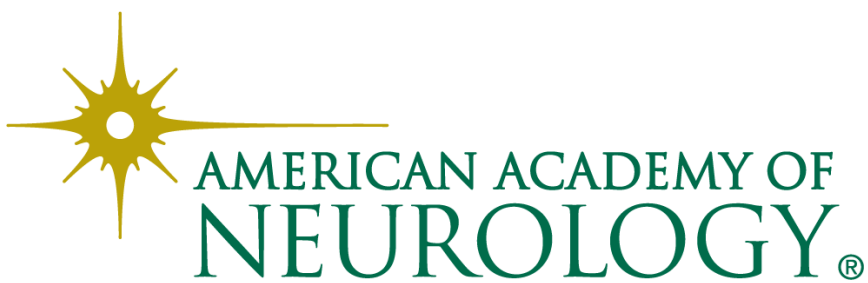

